\title{
Judgement Sebagai Sistem Appraisal dalam Iklan Kecantikan Visual Media Cetak
}

\author{
Riris Tiani \\ Fakultas Ilmu Budaya, Universitas Diponegoro \\ tiani.riris@gmail.com
}

\begin{abstract}
This papper investigated the appraisal system used in the verbal message advertisements visual beauty of each print media. Verbal message visual beauty of each print media were analyzed using appraisal theory which found on domain: attitude. Attitude as negotiating meaning to answer research problems. Judgement as the appraisal which dominate the verbal message advertisement visual beauty of the print media. This study is qualitative and interpretative in which the data analyzed using analysys of appraisal framework to identify categoriez of calusses the establish verbal message advertisement visual beauty of print media. The result showed thet category of clauses that building message advertisement visual beauty of print media dominated by appraisal tool that dominates moral judgement with direct, positive character as a praise and negative character as criticism.
\end{abstract}

Keywords: Appraisal, verbal message, moral judgement.

\section{Intisari}

Penelitian ini bertujuan untuk mengidentifikasi sistem appraisal yang digunakan dalam pesan iklan kecantikan visual di media cetak. Pesan verbal dalam iklan kecantikan visual di media cetak dianalisis dengan menggunakan teori appraisal pada ranah attitude. Attitude sebagai sistem negosiasi menjadi metode analisis dalam mendeskripsikan pesan verbal pada iklan kecantikan visual media cetak. Jenis penelitian ini adalah kualitatif dan interpretatif, sedangkan analisis data menggunakan kerangka kerja analisis appraisal sebagai system negosiasi. Analisis appraisal digunakan untuk mengidentifikasi dan mendeskripsikan klausa sebagai pemarkah pesan verbal pada iklan kecantikan visual media cetak. Hasil penelitian menunjukan bahwa pesan iklan kecantikan visual media cetak didominasi oleh perangkat Moral Judgement secara langsung, berupa pujian yang bersifat positif, dan kritikan yang bersifat negatif.

Kata kunci: Appraisal, pesan verbal, moral judgement.

\section{Pendahuluan}

Dalam menjual berbagai macam barang atau jasa, dibutuhkan suatu strategi agar barang atau jasa tersebut laku. Dengan strategi tertentu diharapkan para khalayak tertarik untuk membeli produk yang ditawarkan. Salah satu trategi yang dapat digunakan dalam menarik perhatian khalayak adalah iklan. Iklan dianggap sebagai sarana efektif untuk menyampaikan pesan dari produsen kepada khalayak. 
Iklan sebagai media promosi yang paling efektif, karena iklan seolah menjanjikan kepuasan tiada batas, menjanjikan keamanan dari rasa takut, menjanjikan keintiman, menjanjikan kecantikan berjuta pesona, dan mendekatkan khalayak pada idolanya. Bahasa iklan menciptakan stimuli di atas ketiga naluri dasar manusia. Bahasa iklan merupakan sebuah komunikasi yang agresif. Komunikasi promorsional harus bisa memaksa (baik secara halus atau langsung) khalayak untuk mengubah perilaku, gaya hidup, dan akhirnya menjadi konsumen setia.

Kekuatan bahasa iklan dalam menghasilkan pencitraan produk sangat dominan dalam menyuburkan cap stereotip yang selama ini dilekatkan pada masyarakat terutama pada perempuan. Selain bahasa iklan yang mengandung kekuatan persuasif, kekuatan dari segi social context iklan direfleksikan melalui tampilan visual iklan, misalnya simbolsimbol sosial yang selama ini dilekatkan pada perempuan, kemudian diolah lebih jauh secara kreatif oleh para pembuat iklan untuk lebih mendekatkan produk yang akan ditawarkan dengan kemauan konsumen. Produk-produk yang ditawarkan berupa Sabun, Susu, Kosmetik, Shampo, dan lainnya selalu menggunakan ikon wanita sebagai alat jual yang cukup signifikan. Penempatan wanita dalam konteks hal ini menunjukan bahwasanya perempuan masih dimaknai sebagi realitas kefisikan yang mampu dijual segala potensi yang ada pada tubuhnya oleh para pemilik modal, terutama pada iklan.

Ada beberapa bentuk iklan yang dimuat di media cetak, seperti iklan kecik, iklan advertorial, dan iklan bergambar atau visual. Berdasar latar belakang yang sudah diuraikan, maka dalam penelitian ini penulis menekankan pada proses persuasi pada iklan kecantikan visual pada media cetak.

Iklan visual pada media cetak tersebut berhubungan dengan kecantikan, seperti iklan kosmetik, iklan suplemen atau jamu kesehatan, iklan sabun dan shampoo, serta iklan pada body lotion yang dihipotesiskan mengandung daya Appraisal.

Tteori Appraisal (TA) merupakan pengembangan dari Linguistik Sistemin Fungsional (LSF) dalam ranah makna interpersonal. Dalam berbahasa, selain ranah makna interpersonal, juga dikenal ranah makna Ideational serta Textual.

Eggins (1994) dalam An Introduction to Systemic Functional Linguistic mendeskripsikan bahwa: "Language is structured to make three main kinds of meanings simultaneously. This semantic complexity, which allows experiantial, interpersonal, and 
textual meaning to be fused together units, is possible because is a semiotic system: a conventionalized coding system, organized as sets of choice."

Jelas bahwa dalam proses berbahasa melibatkan tiga ranah makna yakni, (1) makna experiential, Halliday (1994) menyebutnya dengan makna ideational, (2) makna interpersonal, menekankan hubungan antarindividu, dan (3) makna textual, sesuatu bermakna apabila tervisualkan melaui tulisan. Tulisan-tulisan tersebut dapat terealisasi melalui kata, frasa, dan klausa melalui diksi yang tepat, bahkan tampilan visual yang direfleksikan secara estetik. Dalam Systemic Fungtional Grammar ketiga ranah tersebut disebut dengan metafungsi. Metafungsi pertama adalah Fungsi Ideasional, pada ranah ini berperan dalam konstruksi makna yang berhubungan fisik dan pengalaman pemakai bahasa. Dalam ranah ini, memfokuskan bagaimana pengalaman social seseorang dikonstruksikan dalam bahasa. Ranah kedua yaitu Fungsi Interpersonal, yang berhubungan dengan penyampaian pendapat dan sikap antara penulis dan pembaca, antara pembicara dan pendengar. Fungsi ini menunjukkan tindakan atau aksi yang dilakukan terhadap pengalaman dalam berinteraksi social, yang direalisasikan melalui protoaksi. Interaksi dalam fungsi ini menunjukkan klausa sebagai pokok pertukaran makna. Salah satu penelitian analisis wacana yang sarat dengan makna interpersonal adalah appraisal system sebagai negosiasi sikap yang ada di dalam teks. Ketiga adalah ranah makna pada Fungsi Tekstual. Ranah makna tekstual menjadi penghubung antara maknan ideasional dan interpersonal.

White (1998) membagi ranah teori appraisal menjadi 3 bagian, yakni attitude, amplification, dan sources of attitudes yang menjadi ranah kajian penulis adalah teori appraisal sebagai Attitude. Attitude merupakan evaluasi sikap yang mengacu pada ujaran, pesan verbal, bahkan tindakan yang dikeluarkan oleh orang, maupun terhadap seuatu benda. Evaluasi sikap attitude dapat dibagi menjadi: a. affect (perasaan pembaca), b. appreciation (nilai suatu barang), dan c. judgement (karakter pembaca), penjelasannya sebagai berikut:

\section{a. Affect (feelings)}

Dalam perangkat ini, Affect merupakan evaluasi yang berkaitan dengan perasaan penulis/pembaca. Evaluasi yang mendeskripsikan perasaan penulis atau pembuat iklan kepada pembaca melalui teks pada pesan-pesan verbal iklan kecantikan media cetak, 
bagaimana penilaian mereka secara emosional terhadap seseorang, benda, atau tindakan yang sedang terjadi.

\section{b. Appreciation}

Appreciation merupakan evaluasi terhadap benda yang meliputi sikap misalnya terhadap acara televisi, film, buku, drama, perasaan terhadap sesuatu yang dilihat. Appreciation dapat bersifat positif atau negatif terhadap suatu produk, benda, atau tindakan. Evaluasi appreciation lebih bersifat abstrak, tidak ada justifikasi benar atau salah. Penilaian lebih pada evaluasi estetika dari objek yang ditimbulkan. Misalnya: Rose is beauty. Walaupun dalam hal ini yang dinilai benda, bukan berarti dapat dijustifikasi benar atau salah, baik atau buruk, tetapi secara kodrati mawar tetaplah cantik.

\section{c. Judgement (character)}

Perangkat Judgement adalah pebahasan yang berkaitan dengan penilaian normative penulis akan seseorang. Sebuah penilaian yang berkaitan dengan norma atau konvensi perilaku yang berlaku di masyarakat. Ranah judgement terbagi menjadi dua subsistem yaitu moral judgement dan personal judgement.

\section{(1) Moral Judgement}

Merupakan salah satu subsistem judgemement terbagi atas yang berkaitan dengan hukum perilaku seseorang, misalnya sifat kejujuran dan etika. Moral judgement terbagi atas moral judgement positif (Praise) dan moral judgemen negative (condemn).

\section{(2) Personal Judgement}

Personal Judgemen merupakan penilaian yang berkaitan dengan penilaian oleh seseorang yang diberikan untuk individu yang berhubungan dengan norma-norma di masyarakat. Personal judgement terbagi atas dua subsistem yaitu personal judgemen positif (admire) dan personal judgement negative (criticize).

Oleh karena itu, berdasarkan hipotesis tersebut, penulis tertarik untuk mengetahui lebih jauh mengenai makna interpersonal dengan menggunakan pendekatan Teori Appraisal. Adapun jenis pesan verbal yang yang menjadi obyek penelitian adalah 
pesan verbal pada iklan kecantikan visual media cetak yang muncul dalam tabloid mingguan wanita.

Dalam penelitian ini, penulis menggunakan pendekatan analisis Sistem Appraisal sebagai negotiation attitude, yakni pengembangan teori Functional Grammar pada ranah makna interpersonal. Dengan menggunakan pendekatan Sistem Appraisal, maka dapat mengungkap perangkat Appraisal apa saja yang membangun pesan verbal iklan kecantikan visual media cetak. Berdasarkan uraian di atas, permasalahan dalam penelitian ini terkait dengan perilaku Judgement sebagai Appraisal (appraisal devices) dalam pesan verbal iklan kecantikan visual media cetak.

\section{Metode}

Dalam penelitian ini, korpus data yang digunakan adalah pesan verbal iklan kecantikan visual media cetak, maka penelitian ini termasuk dalam penelitian kepustakan (Library Research). Adapun pendekatan yang dipakai dalam penelitian ini adalah pendekatan analisis wacana (discourse analisys) dengan langkah kerja sebagai berikut:

1) Dalam tahap ini dilakukan pengidentifikasian keseluruhan data, dengan mendaftar pesan-pesan verbal dalam iklan kecantikan visual media cetak. Pesanpesan verbal iklan dari struktur proposisinya menurut Bolen (1984) dalam Advertising terbentuk atas tiga unsure, yaitu (1) pada bagian pembuka (headline), (2) bagian badan (body), dan (3) bagian penutup (close) iklan.

2) Setelah data diidentifikasi, langkah selanjutnya adalah penggolongan data yang berbentuk pesan-pesan verbal dalam iklan kecantikan visual media cetak menggunakan teknik substitusi dan delisi. Dasar penggolongannya sesuai dengan perangkat appraisal yang diduga mengandung Judgement.

3) Data yang sudah digolongkan sesuai dengan perangkat appraisal, selanjutnya ditabulasikan.

4) Langkah selanjutnya adalah mendeskripsikan pesan-pesan verbal iklan kecantikan visual media cetak,

\section{Pembahasan}

\section{Moral Judgement}

Dalam perangkat ini, judgement merupakan evaluasi normative atas perilaku manusia yang berhubungan dengan konvensi perilaku. Judgement berkaitan dengan etika, agama, 
moral, dan segala aturan yang telah disepakati. Dalam penelitian ini penulis menemukan judgement yang bersifat pujian (praise), terlihat pada data berikut:

(1) 'Peraih Most Valuable Brand dalam ajang Indonesian Best Brand Award 2006 untuk kategori bedak wajah dan lisptik'

Pada klausa (1) muncul daya moral judgement yang besifat pujian (praise). Klausa tersebut sengaja ditampilkan pada teks iklan dengan tujuan untuk menunjukkan pada konsumen bahwa produk tersebut merupakan produk yang terbaik diantara produk kosmetik yang lain terutama pada kategoti bedak dan lipstik.

Apabila produsen tidak menampilkan klausa tersebut pada teks iklan, maka konsumen tidak akan menggunakan produk tersebut, mengingat persaingan di pasar kosmetik sangat ketat. Apalagi banyak muncul brandbrand asing yang lebih berkualitas.

(2) 'Karena aku perawan, suamiku jadi penuh kejuatan!'

Kalimat (2) daya moral judgement terrefleksi pada kata 'perawan'. Penilaian normative pada kat 'perawan' dapat dimaknai sebagai bentuk apresiasi seorang istri yang mampu menjaga penampilan jiwa dan ragawi sehingga setelah menikahpun keindahan dari sang istri masih seperti seorang perawan.

Hal tersebut sebagai bentuk tanggung jawab moral sebagai seorang yang berbudaya jawa, senantiasa menjaga warisan nenek moyang untuk selalu mengkonsumsi jamu tradisional. Sehingga kata 'Perawan' dapat disimpulkan mengandung daya moral judgement yang bersifat positif (praise).

(3) 'Gunakan selalu Placenta Treatment Soap with Sirih Extract yang diperkaya dengan Ekstrak Sirih...' 
Penilaian moral judgement yang bersifat (praise) juga tampak pada kalimat (3), terutama pada kata 'gunakan selalu' dan 'ekstrak sirih' yang disampaikan secara tidak langsung oleh penulis.

Data tersebut dikelompokkan dalam moral judgement karena memiliki muatan untuk mempersuasi masyarakat bahwa dengan kita kembali pada perawatan alami, maka akan mendapat manfaat sangat banyak. Kata 'Ekstrak sirih' mengingatkan pembaca supaya lebih memilih perawatan bersifat alami, karena itu produsen menciptakan produk sabun kecantikan yang terbuat dari bahan alami.

Daya persuasi pada bahasa iklan dapat direfleksikan dalam struktur kata, frasa, maupun klausa pada iklan media cetak. Iklan yang akan menjadi sasaran penelitian ini adalah iklan kecantikan visual pada media cetak mingguan. Gejala appraisal negotiation attitude sebuah iklan tampak pada teks iklan berikut:

Pesan verbal pada iklan tersebut dapat dideskripsikan menjadi dua klausa, yakni:

(4) a. New Lipshine Kilau Lembut Menggoda

b. setetes Kesegaran Tropical Juice di bibirmu

Appraisal as negotiation attitudes dalam pesan verbal iklan kecantikan visual di atas dapat deskripsikan sebagai berikut, pada klausa (4a) New Lipshine Kilau Lembut Menggoda, New Lipshine dari kategorialnya frasa tersebut termasuk dalam adverbia. Pemilihan diksi New mempunyai kekuatan positif atau judgement positive dengan tujuan untuk membuat pernyataan bahwa produk pemulas bibir tersebut merupakan produk yang baru. Masyarakat lebih mencari sesuatu yang baru, baik dari komposisi maupun dari kemasan suatu produk.

Berbeda apabila frasa New Lipshine didelisikan menjadi Lipshine, Kilau Lembut Menggoda. Dalam frasa tersebut judgement positive tidak dihadirkan, maka kekuatan untuk mmempengaruhi khalayak kurang begitu kuat, karena produk yang ditawarkan bukan merupakan produk yang baru.

Kategori nomina terrefleksi pada frasa (4b) Setetes Kesegaran Tropical Juice di bibirmu. Pada diksi Setetes yang berkategori nomina, memiliki makna bahwa dengan dipilihnya kata Setetes, seolah-olah khalayak benar-benar dibuat penasaran, hanya dengan setetes lipshine saja, maka kesegaran bibir akan didapat. Pernyataan tersebut 
juga didukung dengan visual seorang model yang sedang meremas buah markisa ditangan. Buah markisa yang mempunyai cita rasa manis asam, bagi yang memakannya pasti akan merasa segar. Visual tersebut dapat merefleksikan bahwa rasa Lipshine dari produk yang ditawarkan memang mempuyai cita rasa manis asam yang penuh kesegaran.

Lain halnya apabila diksi Setetes, pada frasa Setetes Kesegaran Tropical Juice di bibirmu, disubstitusikan dengan dua atau tiga tetes menjadi Dua Tetes Kesegaran Tropical Juice di bibirmu, maka makna iklan verbal tersebut akan berbeda. Perbedaannya terletak pada daya amplifying attitudes yang bersifat focus, bahwa rasa penasaran khalayak terhadap produk tersebut akan menjadi berkurang. Mengapa harus dua tetes, apabila cukup setetes saja akan lebih efisien dan dapat menghemat penggunaan barang sehingga tidak cepat habis.

\section{Personal Judgement}

Personal Judgemen merupakan penilaian yang berkaitan dengan penilaian oleh seseorang yang diberikan untuk individu yang berhubungan dengan norma-norma di masyarakat. Personal judgement terbagi atas dua subsistem yaitu personal judgemen positif (admire) dan personal judgement negative (criticize). Perbedaan moral judgement dan personal judgement adalah personal jugement tidak terfokus pada permasalahan hukum yang berlaku di masyarakat.

(5) 'Dengan Perut Singset...Pakai Baju Apa Saja Jadi Lebih OK!'

Kata 'perut singset' pada data (5) memiliki daya personal judgemen yang bersifat positif (admire). Penilaian personal judgemen dilakukan secara langsung kepada konsumen bahwa setelah menggunakan produk tersebut tak berapa lama konsumen akan mendapatkan bentuk perut yang ideal, sehingga tidak merepotkan ketika mengenakan pakaian bermacam model tanpa membatasi konsumen untuk tampil lebih menarik.

'Saat syuting pasti saya gunakan Fanbo Fantastic. Artisnya maunya pake Fanbo sih....' 
Kata 'saat syuting' memiliki daya personal judgement yang bermuatan negative (criticize) yang disampaikan secara tidak langsung. Kata tersebut justru menjadi kelemahan penulis iklan dalam menggunakan kalimat verbal dalam media cetak.

Penilaian personal judgement bersifat negative karena hanya 'saat syuting' saja para artis menggunakan make up dari produk tersebut. Tetapi disaat artis tidak syuting maka mereka tidak menggunakannya.

Seharusnya produsen tidak perlu menggunakan kata 'saat syuting', kedua kata tersebut memilik makna pembatasan manfaat ketika konsumen akan memilih produk tersebut.

\section{Simpulan}

Judgement sebagai perangkat appraisal berperan penting dalam penentuan penafsiran makna dalam kalimat verbal iklan kecantikan visual media cetak. Perangkat appraisal judgemen yang muncul pada iklan kecantikan visual media cetak terrefleksi dalam bentuk moral judgement dan personal judgement. Moral judgement lebih dominan yang bersifat positif (praise) dan disampaikan secara langsung (direct), sedangkan personal judgement ada yang bersifat positif (admire) dan negative (criticize) yang disampaikan secara tidak langsung (indirect).

\section{Daftar Pustaka}

Bolen, William H. 1994. Advertising. New York:Jhon Wiley \& Sons, Inc Bovee

Eggins, Suzanne. 1994. An Introduction to Systemic Functional Linguistics. London:Pinter Publishers.

Martin, JR and David Rose. 2003. Working with Discourse 'Meaning Beyond The Clause. London:Continuum

Halliday, M.A.K. . 1994. Introduction to Functional Grammar. London: Adward Arnold.

White, P.R.R. 1998. Telling Media Tales: The News Story as Rhetoric. Unpublished research Ph.D Theses. Sydney: University of Sydney. 